\author{
Review Article \\ www.ijrap.net (ISSN:2229-3566)
}

\title{
CONCEPT OF KHAVAIGUNYA IN VYADHYUTPATTI: A REVIEW
}

Supriya $\mathrm{S} *$

Associate Professor, Department of Swasthavritta and Yoga, Yenepoya Ayurveda Medical College and Hospital, Mangalore, Karnataka, India

Received on: 10/06/20 Accepted on: 07/07/20

*Corresponding author

E-mail: supriya.kundapur@gmail.com

DOI: $10.7897 / 2277-4343.1104126$

\section{ABSTRACT}

Vyadhyutpatti has been considered as the process of disease manifestation, it consists of consecutive stages of pathogenesis resulting into a disease. Knowledge of Khavaigunya explains how the vitiated Doshas stagnates in a particular part of body to produce disease, leaving aside many other parts of the body. It also explains about the form of initial disease process after which it leads to clinical manifestation.

Keywords: Khavaigunya, Vyadhyutpatti, Dosha.

\section{INTRODUCTION}

The word "Khavaigunya" comprises of two words 'Kha' and 'Vaigunya'. Meaning of word 'Kha' is space or place'. Meaning of 'Vaigunya' is devoid of normal quality'. Hence the word "Khavaigunya" indicates any space or part of body devoid of normalcy or normal qualities.

According to Ayurveda mere exposure to causative factors will not end up with disease. Instead, existing susceptibility along with exposure to causative factors will result into disease.

\section{Importance of Khavaigunya in Vyadhikriya Kala}

Ayurveda precisely explains the manifestation of disease under the heading 'Vyadhikriya kala'. Here process of disease manifestation is categorised into six stages namely Sanchaya (accumulative stage), Prakopa (provocative stage), Prasara (migration stage), Sthana Samshraya (stage of localization), Vyakti (manifestation stage) and Bheda (stage of complication) successfully ${ }^{3}$.

First stage of pathogenesis includes accumulation of disturbed Doshas (regulatory functional factors of the body) in their own site due to improper diet and lifestyle. If proper measures are not taken and causes are continued, pathogenesis enters the second stage, where Doshas get aggravated. In third stage aggravated Doshas overflow and starts circulating all over the body. In fourth stage of kriyakala (stage of disease manifestation), circulating Doshas if finds any susceptible part in the body, get lodges there resulting in initiation of specific disease process with exhibition of premonitory symptoms of that particular disease. Fifth stage involves clear-cut manifestation of the disease with fully blown signs and symptoms. If particular measures are not taken it enters sixth stage, where disease becomes chronic and difficult to treat ${ }^{4}$.

Here presence of Khavaigunya in the fourth stage of Vyadhi kriyakala is important. Because presence or absence of Khavaigunya decides manifestation or non-manifestation of disease. Agitated and aggravated Doshas (regulatory functional factors of the body) may not end up with disease if host defence mechanism is good.

\section{Causes of Khavaigunya}

In classics it is said that diet and lifestyle that promotes the morbidity of Doshas (regulatory functional factors of the body), go contrary to the wellbeing of dhatus (major structural components of the body), vitiates the respective Srotas (structural or functional Channels) $)^{5}$.

By this explanation we can say that Srotodusti nidanas mentioned in classics goes well with cause of Khavaigunya of that particular Srotas.

\section{Role of Agni in Khavaigunya}

Srotas (structural or functional Channels) transfers dhatus under transformation process (Nutrients part of digested food), along with this Doshas also circulates in the body. Respective Dhatwagni (metabolic factors located in dhatu) act upon this circulating annarasa (nutrients) containing Dhatu Poshaka ingredients to convert them into Sthayi dhatus (tissues).

Impairment in Dhatwagni (metabolic factors located in dhatu) at this level may lead to improper formation of particular dhatu (Sthayi), which causes Dushana (vitiation) of doshas which are in ashraya-ashrayi bhava with particular dhatu. This in turn leads to Vigunata in Srotas; thus, resulting in Khavaigunya of Srotas.

When a person exposes to Vyadhyutpadaka nidana, already existing Khavaigunyata provides favourable condition for Vyadhyutpatti through doshadooshya sammurchana.

\section{Hypothesis regarding types of Khavaigunya}

In Ayurveda classics no direct references are available regarding classification of Khavaigunya, certain hypothesis can be put forth regarding this aspect. 
Khavaigunya may be Hereditary, Congenital or Acquired.

Hereditary variety of Khavaigunya is seen in those individuals carry the hereditary diseases. Epidemiologic studies indicate that age, male gender and certain genetic factors have risk of Atherosclerosis. Some families suffer from frequency of heart attacks at an early age. This familial predisposition is most likely polygenic.

Congenital variety is one in which the person acquires Khavaigunya during intra uterine life. With exposure to minimum causative factors in such individuals there will be Doshadooshya sammurchana resulting into disease. Congenital heart diseases may be considered for congenital variety of Khavaigunya.

Acquired type of Khavaigunya is because of improper diet and lifestyle of an individual.

\section{Role of Khavaigunya in different types of disorders}

Sushruta Samhita categorises diseases under three main headings they are Adhyatmika (psychosomatic disorder), Adibhoutika and Adidaivika $^{6}$. Let us look into role of Khavaigunya in causing these disorders.

Adhyatmika Vyadhis are considered due to constitutional cause i.e. somatic or psychic disturbances. Adhyatmika Vyadhis are of three types they are Aadibalapravrutta, Janmabalapravrutta and Doshabalapravrutta.

The origin of disease in Aadibalapravrutta vyadhi is due to inherent defect of Shukra (sperm) and Shonita (ovum), which forms primary factor for the pathogenesis of disease. In Charaka Samhita it has been mentioned that defect in beeja bhaga or gudavaliarambaka beeja bhaga (part of sperm or ovum from which anal canal will be formed) leads to sahajaarshas.

Recent development in biology and medicine have also emphasized that many disease processes as well as many pathological traits are genetically determined for example, Type 2 diabetes due to genetic defects in beta cell function (chromosome 12, HNF1 alpha (MODY3) 7 .

Genetic factor is considered as one among major constitutional risk factor in atherosclerosis, it plays a significant role in atherogenesis. Hereditary genetic derangements of lipoprotein metabolism predispose the individual to high blood lipid level and familial hypercholesterolaemia ${ }^{8}$.

Hence, we can say that beeja dushti or genetic defect forms Vigunata in certain parts of the body and make them susceptible for disease. So, it can be considered that beeja dushti plays a major role in production of Khavaigunya and further leading to disease.

Disorders belonging to Janmabalapravrutta vyadhi group are considered as congenital type. These occur due to not following proper regimen during gestational period by the pregnant women. There will be development of Khavaigunya in embryo, which in turn lead to diseases after birth. In Charaka Shareera sthana $8^{\text {th }}$ chapter there is a reference regarding this says; if a woman takes alcohol regularly during pregnancy, born baby will suffer from low memory and lack of concentration'.
Recent studies also emphasise that, developmental defects are group of abnormalities during foetal life due to errors in morphogenesis. Exposure to certain chemicals, drugs, physical and biological agents during pregnancy are known to induce such birth defects and are called teratogens ${ }^{10}$.

Doshabalapravrutta vyadhi (diseases caused by vitiated doshas) are those which manifests due to disturbed Manasika and Shareerika doshas by following unhealthy diet and lifestyle ${ }^{11}$. A part of causative factors which are not potent enough to produce diseases immediately are considered as vyanjakanidanas, which may be responsible to produce Khavaigunya in Shareera. Later when individual exposes to disease causing factors, this provides favourable condition for disease manifestation and initiation of pathogenesis of disease takes place. For example, nidanas like exposure to dust and smoke will not lead to Shwasa roga immediately. These factors gradually damage structures of lung producing Khavaigunyata. Later when such individual exposes to potent causes it may end up with Shwasa roga.

Sangatabalapravrutta vyadhis are categorised under Adibhoutika Vyadhis, resulting from external cause or injury ${ }^{12}$. Here external injury may manifest a disease at the site of Khavaigunya or external injury may lead to Khavaigunya. Femoral neck fracture by fall in elderly maybe considered due to reduced bone density. Here already existing reduced bone density in the form of Khavaigunya lead to fracture when exposed to external cause.

Adhyatmika vyadhis are those which are caused by providential causes. Daivabalapravrutta vyadhis (diseases caused by supernatural agencies) are categorised under Adhyatmika vyadhi. Upasargaja vyadhis are considered as one among Daivabalapravrutta Vyadhi. Explanation in classics says that Upasargaja Vyadhis manifests due to close association with diseased person and they spread from one another, like jwara ${ }^{13}$. This explanation holds good for infectious diseases.

Manifestation and effect of infectious diseases depends upon immunity or resistance power of individual to the disease-causing organism. An individual with weak immunity may suffer from infectious diseases frequently. So, we can consider reduced immunity as Khavaigunya in case of infectious diseases.

\section{Importance of knowledge of Khavaigunya in chikitsa}

Health is considered as maintenance of homeostasis of the body. Disturbed homeostasis initiates disease process; during this body immunity fight to resist disease process. Vyadhikshama Shareera has maximum immunity with minimum Khavaigunya. Hence to prevent Khavaigunya in any Srotas Vyadhikshamatva of Srotas is necessary. It can be achieved by following proper diet and lifestyle as per Ayurveda.

\section{CONCLUSION}

Khavaigunya is the space susceptible for pathological changes in Srotas. It may exist structurally or functionally. Due to favourable conditions like nidana, dosha-dushya sammurchana it may lead to diseases.

Even if large amount of vitiated Doshas are circulating in the body, they are not in position to manifest a disease, unless they get favourable place and find a foothold to give rise to a condition known as Sthanasamshraya, without which occurrence of disease is not possible. 
Table 1: Stages of Vyadhikriya kala and importance of Khavaigunya in Vyadhi kriyakala

\begin{tabular}{|c|c|c|}
\hline S. No. & Stages of disease manifestation & Symptoms \\
\hline 1 & Sanchaya & $1^{\text {st }}$ stage of kriyakala. Gradual accumulation of doshas in their respective sites. \\
\hline 2 & Prakopa & $2^{\text {nd }}$ stage of kriyakala. Accumulated Dosha get aggravates in this stage. \\
\hline 3 & Prasara & $\begin{array}{c}3^{\text {rd }} \text { stage of kriyakala. Aggravated dosha circulates all over the body to find a proper } \\
\text { place to get settle }\end{array}$ \\
\hline 4 & Sthanasamshraya & $\begin{array}{c}4^{\text {th }} \text { stage of kriyakala, poorvaroopa of the disease observed. The vitiated dosha circulating } \\
\text { all over the body get lodges at the site of Khavaigunya to produce disease. }\end{array}$ \\
\hline 5 & Vyakti & $5^{\text {th }}$ stage of kriyakala. Clear cut manifestation of the disease with signs and symptoms. \\
\hline 6 & Bheda & $6^{\text {th }}$ kriyakala. Leads to chronicity of disease if not treated. \\
\hline
\end{tabular}

Table 2: Classification of vyadhi based on cause

\begin{tabular}{|c|c|c|c|}
\hline S. No. & Classification & Sub types & Cause \\
\hline \multirow{2}{*}{1} & Adhyatmika & Aadibalapravrutta & Defect in sperm and ovum \\
\cline { 3 - 4 } & & Janmabalapravrutta & Improper diet and lifestyle during gestational period by pregnant lady \\
\cline { 3 - 4 } & & Doshabalapravrutta & Improper diet and life style by the person after birth \\
\hline 2 & Adibhoutika & Sangatabalapravrutta & External Cause like injury \\
\hline 3 & Adidaivika & Kalabalapravrutta & Due to seasonal changes \\
\cline { 3 - 4 } & & Daivabalapravrutta & Providential causes \\
\cline { 3 - 4 } & & Swabhavabalapravrutta & Natural changes in body like aging \\
\hline
\end{tabular}

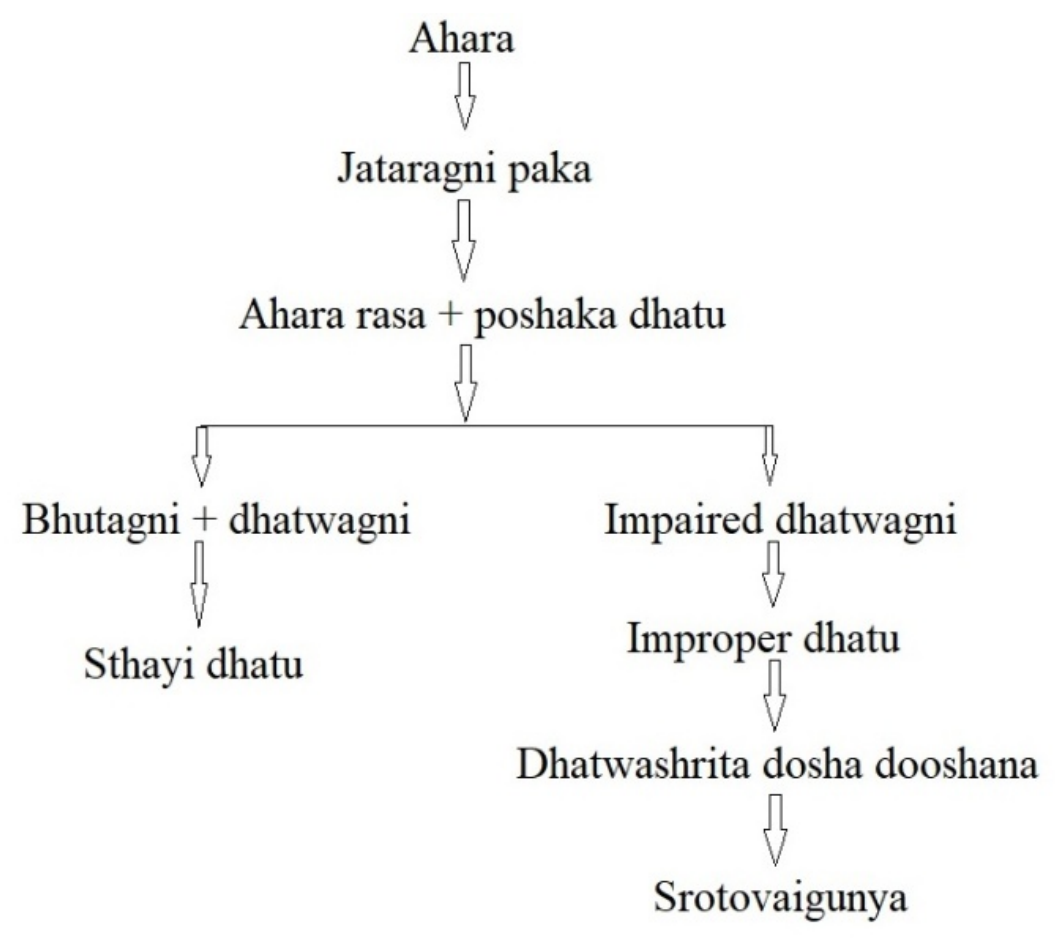

Figure 1: Schematic diagram of role of agni in Khavaigunya

\section{REFERENCES}

1. Syar-Raja-Radhakantdev-Bahadurena, Shabdakalpadruma, $2^{\text {nd }}$ ed, Delhi: Naga Publishers; 2003. p. 267.

2. Syar-Raja-Radhakantdev-Bahadurena, Shabdakalpadruma, $2^{\text {nd }}$ ed, Delhi: Naga Publishers; 2003. p. 335.

3. Sushruta, Sushruta Samhita, Vaidya Yadavji Trikamji Acharya, Narayana Ram Acharya editors, Vrana Prashnaadhyaya, reprint edition 2010,Vranasi: Chaukhambha Sanskrit Sansthan; p. 106.

4. Sushruta, Sushruta Samhita, Vaidya Yadavji Trikamji Acharya, Narayana Ram Acharya editors, Vrana Prashnaadhyaya, reprint edition 2010,Varanasi: Chaukhambha Sanskrit Sansthan; p. 103-106.

5. Agnivesha, Charaka Samhita, Vaidya Yadavji Trikamji Acharya editor, Vimana sthana Srotasam Vimana Adhyaya, edition: reprint, Varanasi: Chaukhambha Prakashan; 2011.p. 242.

6. Sushruta, Sushruta Samhita, Vaidya Yadavji Trikamji Acharya, Narayana Ram Acharya editors, Vyadhisamuddesheeyam Adhyayam, reprint edition 2019, Varanasi: Chaukhambha Orientalia; p. 113.

7. Sir Stanley Davidson. Davidson's principles and practice of Medicine. Stuart H Ralston, Ian D Penman, Mark WJ Strachan, Richard P Hobson, editors. Diabetes mellitus. $23^{\text {rd }}$ edition. Edinburg London: Elsevier; 2018. p. 732, 733.

8. Harsh Mohan. Textbook of Pathology. Blood vessels and Lymphatics. $8^{\text {th }}$ edition. New Delhi: Jaypee Brothers Medical Publishers (P) Ltd; 2019. p. 416.

9. Agnivesha, Charaka Samhita, Vaidya Yadavji Trikamji Acharya editor, Shareera sthana, Jatisutreeyashareera, edition: reprint, Varanasi: Chaukhambha Prakashan; 2011. p. 344. 
10. Harsh Mohan. Textbook of Pathology. Genetics and Paediatric diseases. $8^{\text {th }}$ edition. New Delhi: Jaypee Brothers Medical Publishers (P) Ltd; 2019. p. 287.

11. Sushruta, Sushruta Samhita, Vaidya Yadavji Trikamji Acharya, Narayana Ram Acharya editors, Vyadhisamuddesheeyam Adhyayam, reprint edition, Varanasi: Chaukhambha Orientalia; 2019. p. 114.

12. Sushruta, Sushruta Samhita, Vaidya Yadavji Trikamji Acharya, Narayana Ram Acharya editors, Vyadhisamuddesheeyam Adhyayam, reprint edition, Varanasi: Chaukhambha Orientalia; 2019. p. 114.
13. Sushruta, Sushruta Samhita, Vaidya Yadavji Trikamji Acharya, Narayana Ram Acharya editors, Vyadhisamuddesheeyam Adhyayam, reprint edition, Varanasi: Chaukhambha Orientalia; 2019. p. 114-115.

\section{Cite this article as:}

Supriya S et al. Concept of Khavaigunya in Vyadhyutpatti: A Review. Int. J. Res. Ayurveda Pharm. 2020;11(4):241-244 http://dx.doi.org/10.7897/2277-4343.1104126

\section{Source of support: Nil, Conflict of interest: None Declared}

Disclaimer: IJRAP is solely owned by Moksha Publishing House - A non-profit publishing house, dedicated to publishing quality research, while every effort has been taken to verify the accuracy of the content published in our Journal. IJRAP cannot accept any responsibility or liability for the site content and articles published. The views expressed in articles by our contributing authors are not necessarily those of IJRAP editor or editorial board members. 